OLIVEIRA, FA; DUARTE, SN; MEDEIROS, JF; LIMA, CJGS; OLIVEIRA, MKT; SILVA, RCP. 2017. Improving sweet pepper yield and quality by means of fertigation management. Horticultura Brasileira 35: 235-241. DOI - http://dx.doi.org/10.1590/S0102-053620170213

\title{
Improving sweet pepper yield and quality by means of fertigation management
}

\author{
Francisco A Oliveira ${ }^{1}$; Sergio N Duarte ${ }^{2}$; José F Medeiros ${ }^{1}$; Carlos JGS Lima ${ }^{3}$; Mychelle KT Oliveira ${ }^{1}$; \\ Ricardo CP Silva ${ }^{1}$
}

'Universidade Federal Rural do Semi-Árido (UFERSA), Mossoró-RN, Brasil; thikaoamigao@ufersa.edu.br; jfmedeir@ufersa.edu.br; mymykar@gmail.com; ricarlos_agro@hotmail.com; ${ }^{2}$ Escola Superior de Agricultura Luiz de Queiroz (ESALQ), Piracicaba-SP, Brasil; snduarte@usp.br; ${ }^{3}$ Universidade Federal do Piauí (UFPI), Teresina-PI, Brasil; carloslima@ufpi.edu.br

\begin{abstract}
Fertigation can be managed using fixed fertilizer doses or by assessing the ionic concentration of soil solution throughout the growing period. This work studied how different fertigation management systems affected sweet pepper yield and quality. The experiment was carried out in greenhouse, in pots. Fertigation was managed according to the crop uptake rate $\left(\mathrm{M}_{1}\right)$ or by monitoring either the electrical conductivity $\left(\mathrm{M}_{2}\right)$ or the $\mathrm{N}$ and $\mathrm{K}$ concentration $\left(\mathrm{M}_{3}\right)$ in the soil solution. Fertigation management was combined with six $\mathrm{N}$ and $\mathrm{K}$ doses $(0,50,100,150,200$ and $300 \%$ of the recommended dose for sweet pepper in the region), in complete blocks at random, with four replications, and treatments in 3x6 factorial. Dry matter accumulation, yield and fruit grading were evaluated. Fertigation managed by means of monitoring the soil solution improved the vegetative growth in up to $25 \%$ and increased yield in up to $20 \%$ when compared to management according to the uptake rate. Highest fruit yields in $\mathrm{M}_{1}, \mathrm{M}_{2}$ and $\mathrm{M}_{3}$ were achieved with $\mathrm{N}$ and $\mathrm{K}$ levels corresponding to $127.6 \%$ (1.33 kg/plant), $222.5 \%$ (1.60 $\mathrm{kg} /$ plant) and $215 \%$ (1.48 kg/plant), respectively. $\mathrm{N}$ and $\mathrm{K}$ can be supplied successfully to sweet peppers using electrical conductivity or concentration of ions in the soil solution to manage fertigation. These management systems resulted in high quality fruits and up to $47 \%$ increase in $\mathrm{N}$ and $\mathrm{K}$ use efficiency. $\mathrm{N}$ and $\mathrm{K}$ concentration equivalent to $200 \%$ of the recommended for growing sweet pepper in hydroponics should be taken as reference.
\end{abstract}

Keywords: Capsicum annuum, ionic concentration, porous cup extractors, nitrogen, potassium, electrical conductivity.

\section{RESUMO}

Aumento da produtividade e qualidade do pimentão pelo manejo da fertirrigação

O manejo da fertirrigação pode ser realizado com doses fixas de fertilizantes ou por meio da avaliação da concentração iônica na solução do solo ao longo do período de cultivo. Objetivou-se avaliar diferentes formas de manejo de fertirrigação na cultura do pimentão, com ênfase para a produção e qualidade de frutos. O experimento foi conduzido em casa de vegetação e as plantas foram cultivadas em vasos. Testaram-se três formas de manejo de fertirrigação $\left(\mathrm{M}_{1}\right)$ realizado de acordo com a marcha de absorção da cultura, $\left(\mathrm{M}_{2}\right)$ por meio do monitoramento da condutividade elétrica da solução do solo e $\left(\mathrm{M}_{3}\right)$ por meio do monitoramento da concentração de $\mathrm{N}$ e $\mathrm{K}$. Utilizaram-se seis doses de N e K $(0,50,100,150,200$ e $300 \%$ da dose recomendada para a cultura) em delineamento experimental de blocos casualizados, com esquema fatorial 3x6 e quatro repetições. Avaliou-se o acúmulo de matéria seca, produção e a classificação de frutos. As formas de manejo de fertirrigação com monitoramento da solução do solo $\left(\mathrm{M}_{2}\right.$ e $\left.\mathrm{M}_{3}\right)$ proporcionam desenvolvimento vegetativo até $25 \%$ maior, e acréscimo de produtividade de até $20 \%$ quando comparados com o manejo que segue a marcha de absorção $\left(M_{1}\right)$. Os maiores rendimentos de frutos nos manejos $M_{1}, M_{2}$ e $M_{3}$ foram obtidos para os níveis de $\mathrm{N}$ e $\mathrm{K}$ correspondentes a $127,6 \%$ (1,33 kg/planta), 222,5\% (1,60 kg/planta) $215 \%$ (1,48 kg/planta), respectivamente. $\mathrm{O}$ fornecimento de $\mathrm{N}$ e $\mathrm{K}$ na cultura do pimentão pode ser realizado por intermédio do monitoramento da concentração ou da condutividade elétrica da solução do solo, pois essas formas propiciam melhor qualidade dos frutos e eficiências até $47 \%$ maiores no uso desses nutrientes. Sugere-se utilizar como referencial a concentração de $\mathrm{N}$ e K equivalente a $200 \%$ daquela recomendada para o cultivo hidropônico.

Palavras-chave: Capsicum annuum, concentração iônica, extratores de cápsula porosa, nitrogênio, potássio, condutividade elétrica.

\section{Received on October 13, 2016; accepted on April 10, 2017}

$\mathrm{S}$ weet peppers (Capsicum annuum) are among the leading vegetables in Brazil, both in terms of production and consumption. Figures are around 13 thousand hectares used for production and an estimate of 290 thousand tons of sweet peppers harvested (Marouelli
\& Silva, 2012). The state of São Paulo is the main producer, with an annual estimate of about 80 thousand tons and an area of 2.4 thousand hectares (IEA, 2015). Sweet peppers are grown predominantly in the open field, but protected cultivation has been expanding practically all over the country (Oliveira et al., 2015).

Fertigation is very usual in protected cultivation, especially when localized irrigation systems are in place (Oliveira \& Villas Boas, 2008). Fertigation scales up input use in many irrigated crops 
in aspects related to both productivity and product quality. Nitrogen and potassium are the nutrients more often applied via irrigation water, since both fit perfectly into the system due to their high mobility in the soil and solubility of almost $100 \%$ in water. Moreover, and specifically when sweet peppers are considered, $\mathrm{N}$ and $\mathrm{K}$ are the nutrients exported in the largest amounts (Marcussi et al., 2004; Fontes et al., 2005). $\mathrm{N}$ is related to photosynthesis, respiration, root development and activity, ionic uptake of other nutrients, and cell growth and differentiation. $\mathrm{K}$ improves fruit physical and chemical characteristics by optimizing processes such as transpiration and carbohydrate synthesis (Taiz \& Zeiger, 2009).

For fertigation to be efficient, a balance between the amount of nutrients and the volume of water applied at each stage of the crop cycle must be found. Water and nutrient availability should be close to the optimal for crop development and yield (Blanco \& Folegatti, 2002). Excessive application of fertilizers causes physiological disorders, such as drops in fruit yield and quality, nutritional imbalance and increases in osmotic pressure (Epstein \& Bloom, 2006).

Fertigation is traditionally managed by supplying pre-established fertilizer amounts, split according to the crop uptake curve. It is not usual to monitor the ion concentration in the soil solution or the plant nutritional status (Papadopoulos, 1999). Medeiros et al. (2012), working with tomatoes in protected cultivation, found that fertigation management as recommended by literature may lead to an overestimation of fertilizer requirements, drastically reducing the nutrient efficiency use by plants.

In addition to the adequate fertilizer dose, another key factor is how fertilizers are supplied throughout the crop cycle (Oliveira et al., 2013). Instead of pre-established doses, it is wiser to rationalize fertigation management by determining the electrical conductivity and/or partial concentration of ions in the soil solution, allowing for necessary adjustments along the crop cycle (Dias et al., 2005). In this framework, several researchers have been obtaining very satisfactory results using porous cup soil-water extractors, either to monitor the electrical conductivity (Medeiros et al., 2012; Silva et al., 2013) or the concentration of ions in the soil solution (Silva Júnior et al., 2010; Oliveira et al., 2013, 2015). However, studies comparing these two fertigation management systems are scarce in literature.

Given the aforesaid, the present work was carried out to evaluate fertigation management in sweet peppers grown in protected cultivation, with emphasis on biomass production and fruit yield and grading.

\section{MATERIAL AND METHODS}

The experiment was carried out from June to November 2010, in greenhouse, in the Rural Federal University of the Semi-Arid, in the city of Mossoró, state of Rio Grande do Norte, Brazil

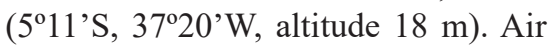
temperature and relative humidity during the experimental period were measured with a digital thermo-hygrometer (Mod. 30.5000.02, TFA Technology $\mathrm{HK}$ ), installed $1.5 \mathrm{~m}$ from the ground, in the middle of the greenhouse. The experiment was set in complete blocks at random, with treatments in 3x6 factorial, and four replications. Experimental plots consisted of $25 \mathrm{~L}$ pots, one plant per pot. Pots were arranged over $10-\mathrm{cm}$ high masonry bricks and distributed in four rows, with $1.5 \mathrm{~m}$ spacing between rows and $0.50 \mathrm{~m}$ between pots, resulting in a density equivalent to 13,333 plants/ ha.

Treatments consisted in combining three fertigation management systems $\left(M_{1}\right)=$ crop uptake rate (Table 1$)$; $\left(M_{2}\right)=$ monitoring of the soil solution conductivity, and; $\left(\mathrm{M}_{3}\right)=$ monitoring of the concentration of $\mathrm{N}$ and $\mathrm{K}$ ions in the soil solution and $\operatorname{six} \mathrm{N}$ and $\mathrm{K}$ proportional levels $\left(\mathrm{N}_{0} \mathrm{~K}_{0}, \mathrm{~N}_{50} \mathrm{~K}_{50}\right.$, $\mathrm{N}_{100} \mathrm{~K}_{100}, \mathrm{~N}_{150} \mathrm{~K}_{150}, \mathrm{~N}_{200} \mathrm{~K}_{200}$ and $\mathrm{N}_{300} \mathrm{~K}_{300}$ ). In $\mathrm{M}_{2}$ and $\mathrm{M}_{3}$ management systems, $\mathrm{N}$ and $\mathrm{K}$ were supplied whenever electrical conductivity levels $\left(\mathrm{M}_{2}\right)$ or $\mathrm{N}$ and $\mathrm{K}$ concentration $\left(\mathrm{M}_{3}\right)$ were reduced by $20 \%$ in relation to initial values. For the $\mathrm{M}_{1}$ management system, $\mathrm{N}_{100} \mathrm{~K}_{100}$ level corresponded to the $\mathrm{N}$ and $\mathrm{K}$ recommended doses for sweet pepper in the region of Mossoró, namely 215 and $314 \mathrm{~kg} / \mathrm{ha}$ of $\mathrm{N}$ and $\mathrm{K}$, respectively, distributed throughout the cycle (Freitas, 2009). For $\mathrm{M}_{2}$ and $\mathrm{M}_{3}$ management systems, $\mathrm{N}_{100} \mathrm{~K}_{100}$ level corresponded to the recommended $\mathrm{N}$ and $\mathrm{K}$ concentration for sweet peppers in NFT hydroponic system, namely 152 and $245 \mathrm{mg} / \mathrm{L}$ for $\mathrm{N}$ and $\mathrm{K}$, respectively (Castellane \& Araújo, 1994).

Levels of electrical conductivity $\left(\mathrm{M}_{2}\right)$ and $\mathrm{N}$ and $\mathrm{K}\left(\mathrm{M}_{3}\right)$ refer to the concentration of these nutrients in the soil solution, collected through porous cup extractors. Adjustment curves obtained in previous calibration (Oliveira et al., 2013) were used to correlate both the $\mathrm{N}$ and $\mathrm{K}$ doses to be used in $\mathrm{M}_{2}$ and $\mathrm{M}_{3}$ management systems to electrical conductivity values. The following levels were established: 0.6; $1.6 ; 2.2 ; 3.1 ; 3.8$ and $4.4 \mathrm{dS} / \mathrm{m}$, for $\mathrm{N}$ and $\mathrm{K}\left(\mathrm{N}_{0} \mathrm{~K}_{0}, \mathrm{~N}_{76} \mathrm{~K}_{123}, \mathrm{~N}_{152} \mathrm{~K}_{245}, \mathrm{~N}_{228} \mathrm{~K}_{368}\right.$, $\mathrm{N}_{304} \mathrm{~K}_{490}$ and $\mathrm{N}_{456} \mathrm{~K}_{736}, \mathrm{mg} / \mathrm{L}$ ).

The soil used in the experiment came from a profile classified as Haplic Acrisol (FAO, 1994), with the following characteristics (Embrapa, 2009): $\mathrm{pH}=$ 5.9; $\mathrm{OM}=1.05 \% ; \mathrm{P}=2.2 \mathrm{mg} / \mathrm{dm}^{3} ; \mathrm{K}=$ $0.14 \mathrm{cmol}_{\mathrm{c}} / \mathrm{dm}^{3} ; \mathrm{Na}=0.40 \mathrm{cmol} / \mathrm{dm}^{3}$; $\mathrm{Ca}=0.40 \mathrm{cmol}_{\mathrm{c}} / \mathrm{dm}^{3} ; \mathrm{Mg}=0.60 \mathrm{cmol}_{\mathrm{c}} /$ $\mathrm{dm}^{3} ; \mathrm{Al}=0.05 \mathrm{cmol} / \mathrm{dm}^{3}$ and; $\mathrm{H}=2.05$ $\mathrm{cmol}_{\mathrm{c}} / \mathrm{dm}^{3}$.

The sweet pepper hybrid Atlantis (Topseed), one of the most popular in the region, was used. Hybrid Atlantis is adapted to both field and greenhouse conditions, has high yielding potential, 120-day average cycle and tolerance to the Pepper Yellow Mosaic Virus (PepYMV). Fruits are rectangular, dark green before maturation and red-intense when ripe (Agristar). We planted 35-day old seedlings, purchased from a nursery in the city of Icapuí, in the neighboring state of Ceará.

The drip irrigation system consisted of $1.000 \mathrm{~L}$ water tank installed on 1.0 $\mathrm{m}$ high wooden bench, polyethylene lateral lines (16 mm), manual shut-off valves, $0.5 \mathrm{~m}$ long microtube (spaghetti) emitters, $1 \mathrm{~mm}$ internal diameter, and $1.76 \mathrm{~L} /$ hour ( $\pm 0.1 \mathrm{~L} /$ hour) average flow rate. The volume of water used 
for irrigation was determined from the soil-water tension, measured by $15 \mathrm{~cm}$ depth tensiometers. Soil-water tension was converted to humidity using a soil-water retention curve [U $=124.53 \mathrm{~T}^{-0.9419}$, where $\mathrm{U}=$ current soil moisture $(\mathrm{kg} / \mathrm{kg})$ and $\mathrm{T}=$ soil-water tension $(\mathrm{kPa})]$. Irrigation was carried out applying the volume necessary to raise soil moisture to field capacity. In addition to tensiometers, $15 \mathrm{~cm}$ depth solution extractors were also installed in each pot to collect and monitor soil solution. Nutrient concentration in the solution collected by extractors was corrected to restore the same moisture as at field capacity.

Top fertilizations were carried out via fertigation throughout the crop cycle. For management $M_{1}$, fertigation took place every four days, according to the crop uptake rate. Fertilizer solutions were applied individually in each pot, without wetting plant stems, using a $500 \mathrm{~mL}$ beaker and the same volume in all pots. Nutrient sources were calcium nitrate, potassium chloride, potassium monobasic phosphate, potassium nitrate, sodium nitrate, calcium chloride, magnesium sulfate and phosphoric acid. In management systems $\mathrm{M}_{2}$ and $\mathrm{M}_{3}$, fertigation were carried out according to the analysis of the solution collected with extractors. Fertigation took place whenever electrical conductivity $\left(\mathrm{M}_{2}\right)$ or $\mathrm{N}$ and $\mathrm{K}$ concentration $\left(\mathrm{M}_{3}\right)$ were reduced by $20 \%$ in relation to the initial value, applying the volume necessary to raise soil moisture to field capacity. $\mathrm{P}, \mathrm{Ca}, \mathrm{Mg}$ and $\mathrm{S}$ were applied regularly in the control treatment, without $\mathrm{N}$ and $\mathrm{K}\left(\mathrm{N}_{0} \mathrm{~K}_{0}\right)$, to limit plant response to variations in $\mathrm{N}$ and $\mathrm{K}$ levels. Accumulated $\mathrm{N}$ and $\mathrm{K}$ amounts (g/plant), corresponding to the applications during and until the end of the experiment are presented in Table 2.

Foliar micronutrient applications were carried out weekly using an EDTAchelated solid mixture containing $0.28 \%$ $\mathrm{Cu}, 7.5 \% \mathrm{Fe}, 3.5 \% \mathrm{Mn}, 0.7 \% \mathrm{Zn}, 0.65 \%$ $\mathrm{B}$ and $0.3 \%$ Mo (Quelatec AZ), in the dose recommended for sweet pepper, i.e., $2.50 \mathrm{~kg} / \mathrm{ha}, 70$ and at 90 days after transplanting. Weekly foliar applications of $\mathrm{CaB}_{2}$ ( $2 \%$ boron and $10 \%$ calcium) were also carried out, following the manufacturer's recommendations, to provide $\mathrm{Ca}$ and $\mathrm{B}$, important in the fruiting phase. Insecticides Imidacloprid + Cyfluthrin (Confidor 700 WG), Abamectin (Vertimec 18 EC) and Acephate (Othene) and fungicides Chlorothalonil (Daconil-BR) and Azoxystrobin (Amistar) were sprayed biweekly throughout the experiment, alternating active principles, in the recommended dosages.

Six harvests were carried out during the experiment, the first 60 and the last 120 days after planting (DAT), with harvests occurring as fruits reach maturation. Fruits were harvested when bright dark green and at commercial size (CEAGESP, 2014), i.e., length and diameter greater than 60 and $40 \mathrm{~mm}$, respectively. In all harvests, fruits were graded by length $(\mathrm{cm})$ : class 4 (from 4 to $6 \mathrm{~cm}$ ), class 6 (from 6 to $8 \mathrm{~cm}$ ), class 8 (from 8 to $10 \mathrm{~cm}$ ), class 10 (from 10 to $12 \mathrm{~cm}$ ), class 12 (from 12 to 15 $\mathrm{cm}$ ), class 15 (from 15 to $18 \mathrm{~cm}$ ), class 18 (from 18 to $21 \mathrm{~cm}$ ), class 21 (from 21 to $24 \mathrm{~cm}$ ) and class 24 (greater than $24 \mathrm{~cm}$ ) (CEAGESP, 2014). Fruit length and diameter were measured with digital caliper. At the end of the experiment (120 DAT), plants were collected, separated in stems, leaves and fruits, and dried in oven with forced air circulation, $65^{\circ} \mathrm{C}$, until constant mass. Dry mass of each part was determined using a precision scale $(0.01 \mathrm{~g})$ and total dry mass was calculated by summing all parts.

Data were submitted to analysis of variance, applying $\mathrm{F}$ test and unfolding the significant interactions. Regression analysis was applied to the quantitative factor, $\mathrm{N}$ and $\mathrm{K}$ levels. For the qualitative factor, fertigation management systems, means were separated by Tukey test, $\mathrm{p}>0.05$. Fruit grading was analyzed by descriptive statistics, studying the distribution frequency in classes. Statistical analyzes were performed using the statistical software Sisvar 4.1 (Ferreira, 2008).

\section{RESULTS AND DISCUSSION}

Fertigation management by monitoring either the electrical conductivity (EC) or the ion concentration in the soil solution (treatments $M_{2}$ and $M_{3}$, respectively) resulted in higher stem, leaf, fruit and total dry mass when compared to the management based on the crop uptake rate (treatment $\mathrm{M}_{1}$ ), mainly in the higher $\mathrm{N}$ and $\mathrm{K}$ levels (Table 3 ).

The superiority in biomass production observed in $\mathrm{M}_{2}$ and $\mathrm{M}_{3}$ over $M_{1}$ shows the importance of monitoring soil solution, either through the concentration of $\mathrm{N}$ and $\mathrm{K}$ ions or through the electrical conductivity. Both strategies allow a better ionic balance during crop cycle than fertigation management through the absorption rate $\left(M_{1}\right)$, which does not monitor, nor controls salt concentration in the soil. Other authors also verified more biomass accumulation when managing fertigation by monitoring soil solution in other crops, such as tomato (Medeiros et al., 2012) and eggplant (Silva et al., 2013).

The effects of $\mathrm{N}$ and $\mathrm{K}$ levels over stem dry mass were adjusted to the following quadratic models: $\mathrm{M}_{1}=$ $-0.00071 * * \mathrm{X}^{2}+0.211 * * \mathrm{X}+31.87$; $\mathrm{R}_{2}=0.56 * ; \mathrm{M}_{2}=-0.0012 * * \mathrm{X}^{2}+$ $0.454 * * \mathrm{X}+27.82, \mathrm{R}_{2}=0.97 * *$, and; $\mathrm{M}_{3}=-0.00091 * * \mathrm{X}^{2}+0.355 * * \mathrm{X}+$ $31.18, R_{2}=81 *$. Using these equations, the highest stem dry mass values were estimated to be reached at $155.1 \%$ for $\mathrm{M}_{1}(48.2 \mathrm{~g} / \mathrm{plant}), 189.2 \%$ for $\mathrm{M}_{2}(70.8$ $\mathrm{g} /$ plant) and $197.2 \%$ for $\mathrm{M}_{3}(66.2 \mathrm{~g} /$ plant), which would correspond to stem dry matter increases of $51.4 \%$ $\left(\mathrm{M}_{1}\right), 154.4 \%\left(\mathrm{M}_{2}\right)$ and $112.3 \%\left(\mathrm{M}_{3}\right)$ if compared to values obtained in $\mathrm{N}$ and $\mathrm{K}$ absence (Table 3).

Leaf dry mass also showed quadratic response to the increasing $\mathrm{N}$ and $\mathrm{K}$ levels in the three fertigation management systems analyzed: $\mathrm{M}_{1}=-0.0010 * * \mathrm{X}^{2}$ $+0.315 * * \mathrm{X}+22.91, \mathrm{R}_{2}=0.73 * ; \mathrm{M}_{2}$ $=-0.0012 * * X^{2}+0.475 * * X+20.16$, $\mathrm{R}_{2}=0.96 * *$, and $; \mathrm{M}_{3}=-0.00091 * * \mathrm{X}^{2}$ $+0.366 * * \mathrm{X}+21.68, \mathrm{R}_{2}=0.88 * *$. Maximum leaf dry mass values were estimated at $157.5 \% \mathrm{~N}$ and $\mathrm{K}$ for the fertigation management $M_{1}(47.7 \mathrm{~g} /$ plant $), 197.9 \%$ for $\mathrm{M}_{2}(67.2 \mathrm{~g} / \mathrm{plant})$ and $212.9 \%$ for $\mathrm{M}_{3}(63.8 \mathrm{~g} / \mathrm{plant})$, representing increases of $108.3 \%$, $233.2 \%$ and $194.4 \%$ when compared 
to the leaf dry mass obtained in the absence of $\mathrm{N}$ and $\mathrm{K}$, for the fertigation management systems $M_{1}, M_{2}$ and $M_{3}$, respectively (Table 3 ). These differences can be attributed to the largest development of leaves in relation to the stem, possibly leading to higher nutritional demands.

Variation in fruit dry mass as function of increasing $\mathrm{N}$ and $\mathrm{K}$ levels were also adjusted to quadratic models $\left(\mathrm{M}_{1}=-0.0019 * \mathrm{X}^{2}+0.467 * \mathrm{X}+38.65, \mathrm{R}_{2}\right.$ $=0.55 * ; \mathrm{M}_{2}=-0.0016 * * \mathrm{X}_{2}+0.638^{* *} \mathrm{X}$ $+28.34, \mathrm{R}_{2}=0.91 * * ; \mathrm{M}_{3}=-0.0021 * * \mathrm{X} 2$ $\left.+0.675 * * \mathrm{X}+35.70, \mathrm{R}_{2}=0.72 *\right)$. Fruit dry mass increased up to $122.9 \%$ for $M_{1}, 199.7 \%$ for $M_{2}$ and $160.7 \%$ for $\mathrm{M}_{3}$, reaching maximum values of 67.3 ; 92.2 and $89.9 \mathrm{~g}$ of fruit dry mass per plant for $M_{1}, M_{2}$ and $M_{3}$, respectively (Table 3). Although in $M_{1}$ the highest fruit dry mass occurred at lower $\mathrm{N}$ and $\mathrm{K}$ levels than in the other fertigation management systems, fruit dry mass in $M_{1}$ increased only $74.2 \%$ in relation to the control, while much more expressive gains occurred in $\mathrm{M}_{2}(225.0 \%)$ and $\mathrm{M}_{3}$ $(151.9 \%)$.

Using the regression equations for total dry mass in each fertigation management $\left(\mathrm{M}_{1}=-0.0035 * * \mathrm{X}^{2}+\right.$ $0.994 * *+93.44, \mathrm{R}_{2}=0.63 * ; \mathrm{M}_{2}=$ $-0.0040 * * \mathrm{X}^{2}+1.5685^{* *} \mathrm{X}+76.33, \mathrm{R}_{2}=$ $0.96 * * ; \mathrm{M}_{3}=-0.0039 * * \mathrm{X}^{2}+1.428 * * \mathrm{X}$ $\left.+88.57, \mathrm{R} 2=0.79^{* *}\right)$, the highest total dry mass values were estimated for $\mathrm{N}$ and $\mathrm{K}$ levels corresponding to $142.0 ; 196.0$ and $183.1 \%$, with total mass accumulation corresponding to $164.0 ; 230.0$ and $219.0 \mathrm{~g} / \mathrm{plant}$, for fertigation management systems $M_{1}$, $\mathrm{M}_{2}$ and $\mathrm{M}_{3}$, respectively (Table 3). As observed for stem, leaf and fruit dry mass, more expressive response in total dry mass were observed for $\mathrm{M}_{2}$ $(201.3 \%)$ and $M_{3}(147.6 \%)$, while $M_{1}$ resulted in lower gain $(75.5 \%)$ when estimates were compared to the total dry mass observed in the absence of $\mathrm{N}$ and $\mathrm{K}$ fertilization (Table 3). Medeiros et al. (2012) observed similar results in tomatoes grown in protected cultivation, also observing quadratic effects on the accumulation of biomass in response to increases in ion concentration in the soil solution.

Fertigation management systems

Table 1. Nitrogen and potassium supply by fertigation according to the crop uptake rate. Mossoró, UFERSA, 2010.

\begin{tabular}{lcc}
\hline Days after transplanting & Nitrogen (\%) & Potassium (\%) \\
\hline $1-14$ & 3.4 & 3.3 \\
$15-28$ & 9.6 & 10.8 \\
$29-42$ & 10.2 & 11.6 \\
$43-56$ & 13.9 & 12.9 \\
$57-70$ & 11.8 & 11.6 \\
$71-84$ & 14.5 & 14.3 \\
$85-98$ & 12.6 & 13.2 \\
$99-112$ & 12.9 & 12.5 \\
$113-120$ & 11.1 & 9.8 \\
\hline
\end{tabular}

Table 2. Amounts of nitrogen and potassium (g/plant) supplied in the three different fertigation management systems. Mossoró, UFERSA, 2010.

\begin{tabular}{|c|c|c|c|c|c|c|}
\hline \multirow{2}{*}{$\begin{array}{l}\mathrm{N} \text { and } \mathrm{K} \\
\text { level }(\%)^{1}\end{array}$} & \multicolumn{2}{|c|}{$\mathbf{M}_{1}{ }^{2}$} & \multicolumn{2}{|c|}{$\mathbf{M}_{2}^{2}$} & \multicolumn{2}{|c|}{$\mathbf{M}_{3}^{2}$} \\
\hline & $\mathbf{N}$ & K & $\mathbf{N}$ & $\mathbf{K}$ & $\mathbf{N}$ & K \\
\hline 0 & 0.00 & 0.00 & 0.00 & 0.00 & 0.00 & 0.00 \\
\hline 50 & 6.00 & 6.65 & 3.26 & 8.95 & 4.06 & 6.31 \\
\hline 100 & 11.65 & 13.29 & 6.58 & 11.59 & 6.68 & 10.41 \\
\hline 150 & 17.47 & 19.55 & 10.11 & 16.38 & 8.39 & 12.92 \\
\hline 200 & 23.33 & 26.59 & 13.88 & 22.10 & 11.96 & 19.00 \\
\hline 300 & 29.16 & 33.24 & 21.68 & 29.27 & 12.22 & 19.14 \\
\hline
\end{tabular}

${ }^{1} 100 \%$ equals to 215 and $314 \mathrm{~kg} /$ ha of $\mathrm{N}$ and $\mathrm{K}$, respectively (Freitas, 2009); ${ }^{2} \mathrm{M}_{1}=$ fertigation managed according to the crop uptake rate; $\mathrm{M}_{2=}$ fertigation managed by monitoring the electrical conductivity of the soil solution; $\mathrm{M}_{3=}$ fertigation managed by monitoring $\mathrm{N}$ and $\mathrm{K}$ ionic concentration in the soil solution.

$\mathrm{M}_{2}$ (monitoring of the electrical conductivity) and $\mathrm{M}_{3}$ (monitoring ion concentration in the soil solution) resulted in the highest fruit yield per plant at high $\mathrm{N}$ and $\mathrm{K}$ levels. Even though, the fertigation management system requiring the highest $\mathrm{N}$ dose was M1 (crop uptake rate) (Table 4). Thus, monitoring and controlling either the electrical conductivity or the ionic concentration of the soil solution may have allowed better nutritional conditions for plants, leading to higher yields, as also seen by Medeiros et al. (2012) and Silva et al. (2013).

Effects of $\mathrm{N}$ and $\mathrm{K}$ levels on sweet pepper production were adjusted to quadratic regression equations independently of the fertigation management system $\left(\mathrm{M}_{1}=-0.032 * * \mathrm{X}^{2}\right.$ $+8.165^{*} \mathrm{X}+804.7, \mathrm{R}_{2}=0.71 * ; \mathrm{M}_{2}=$ $-0.018 * \mathrm{X}^{2}+8.010 * * \mathrm{X}+709.8, \mathrm{R}_{2}=$ $0.63 * ; \mathrm{M}_{3}=-0.014 * * \mathrm{X}^{2}+6.019 * * \mathrm{X}$ $\left.+828.8, \mathrm{R}_{2}=0.55^{*}\right) . \mathrm{N}$ and $\mathrm{K}$ doses estimated to result in the highest yields corresponded to $127.6 \%\left(\mathrm{M}_{1}\right)$, $222.5 \%\left(\mathrm{M}_{2}\right)$ and $215.0 \%\left(\mathrm{M}_{3}\right)$ of the doses recommended by other authors for growing sweet peppers, either in conventional fertigation $\left(\mathrm{M}_{1}\right)$ or in hydroponics $\left(\mathrm{M}_{2}\right.$ and $\left.\mathrm{M}_{3}\right)$ (Table 4$)$. The highest estimated yields were $1.33 \mathrm{~kg} /$ plant for $\mathrm{M}_{1} ; 1.60 \mathrm{~kg} /$ plant for $\mathrm{M}_{2}$ and; $1.48 \mathrm{~kg} / \mathrm{plant}$ for M3, which corresponds to increases in relation to the control treatment of $64.7 \%\left(\mathrm{M}_{1}\right), 125.5 \%\left(\mathrm{M}_{2}\right)$ and $78.1 \%\left(\mathrm{M}_{3}\right)$ (Table 4).

Comparing the $\mathrm{N}$ and $\mathrm{K}$ levels which, by estimation, would result in the highest sweet pepper yields, to the doses applied in the experiment (Table 2), those top-yielding levels would be equivalent to doses of approximately (in $\mathrm{g}$ of $\mathrm{N}$ and $\mathrm{K}$ per plant, respectively) 14 and $18\left(\mathrm{M}_{1}\right)$; 15 and $23\left(\mathrm{M}_{2}\right)$ and; 10 and $16 \mathrm{~g}\left(\mathrm{M}_{3}\right)$. It can be seen that management $\mathrm{M}_{3}$, besides outyielding $\mathrm{M}_{1}$, had a higher ratio yield: $\mathrm{N}$ and $\mathrm{K}$ 
Table 3. Stem, leaf, fruit and total dry weight of sweet pepper grown in protected cultivation with different fertigation management systems and nitrogen and potassium levels. Mossoró, UFERSA, 2010.

\begin{tabular}{|c|c|c|c|c|c|c|c|}
\hline \multirow{2}{*}{$\begin{array}{l}N \text { and } K \\
\text { level } \\
(\%)^{1}\end{array}$} & $\mathbf{M}_{1}^{2}$ & $\mathbf{M}_{2}^{2}$ & $\mathbf{M}_{3}{ }^{2}$ & \multirow{2}{*}{$\begin{array}{l}N \text { and } K \\
\text { level } \\
(\%)^{1}\end{array}$} & $\mathbf{M}_{1}^{2}$ & $\mathbf{M}_{2}^{2}$ & $\mathbf{M}_{3}^{2}$ \\
\hline & \multicolumn{3}{|c|}{ Stem dry mass (g/plant) } & & \multicolumn{3}{|c|}{ Leaf dry mass (g/plant) } \\
\hline 0 & $26.1 \mathrm{a}$ & $26.1 \mathrm{a}$ & $26.1 \mathrm{a}$ & 0 & $17.2 \mathrm{a}$ & $17.2 \mathrm{a}$ & $17.2 \mathrm{a}$ \\
\hline 50 & $51.7 \mathrm{a}$ & $52.3 \mathrm{a}$ & $55.9 \mathrm{a}$ & 50 & $47.9 \mathrm{a}$ & $45.5 \mathrm{a}$ & $44.7 \mathrm{a}$ \\
\hline 100 & $45.5 \mathrm{~b}$ & $58.3 \mathrm{a}$ & $54.4 \mathrm{a}$ & 100 & $41.5 \mathrm{~b}$ & $55.3 \mathrm{a}$ & $53.7 \mathrm{a}$ \\
\hline 150 & $42.7 \mathrm{~b}$ & $67.3 \mathrm{a}$ & $68.9 \mathrm{a}$ & 150 & $45.5 \mathrm{~b}$ & $65.8 \mathrm{a}$ & $64.5 \mathrm{a}$ \\
\hline 200 & $47.4 \mathrm{~b}$ & $72.2 \mathrm{a}$ & $58.8 \mathrm{a}$ & 200 & $47.6 \mathrm{c}$ & $62.5 \mathrm{a}$ & $54.3 \mathrm{~b}$ \\
\hline 300 & $35.4 \mathrm{~b}$ & $55.6 \mathrm{a}$ & $59.2 \mathrm{a}$ & 300 & $32.6 \mathrm{~b}$ & $55.3 \mathrm{a}$ & $60.3 \mathrm{a}$ \\
\hline \multicolumn{5}{|c|}{ Fruit dry mass (g/plant) } & \multicolumn{3}{|c|}{ Total dry mass (g/plant) } \\
\hline 0 & $21.0 \mathrm{a}$ & $21.0 \mathrm{a}$ & $21.0 \mathrm{a}$ & 0 & $64.2 \mathrm{a}$ & $64.22 \mathrm{a}$ & $64.2 \mathrm{a}$ \\
\hline 50 & $75.7 \mathrm{a}$ & $65.1 \mathrm{~b}$ & $87.3 \mathrm{a}$ & 50 & $175.3 \mathrm{a}$ & $162.8 \mathrm{~b}$ & $187.9 \mathrm{a}$ \\
\hline 100 & $89.9 \mathrm{a}$ & $84.6 \mathrm{a}$ & $84.5 \mathrm{a}$ & 100 & $176.9 \mathrm{~b}$ & $198.2 \mathrm{a}$ & $192.6 \mathrm{a}$ \\
\hline 150 & $54.9 \mathrm{~b}$ & $83.1 \mathrm{a}$ & $86.9 \mathrm{a}$ & 150 & $143.1 \mathrm{~b}$ & $216.2 \mathrm{a}$ & $220.3 \mathrm{a}$ \\
\hline 200 & $36.6 \mathrm{~b}$ & $86.7 \mathrm{a}$ & $74.4 \mathrm{a}$ & 200 & $149.6 \mathrm{c}$ & $221.4 \mathrm{a}$ & $187.5 \mathrm{~b}$ \\
\hline 300 & $20.6 \mathrm{c}$ & $82.5 \mathrm{a}$ & $56.2 \mathrm{~b}$ & 300 & $88.6 \mathrm{~b}$ & $193.5 \mathrm{a}$ & $175.7 \mathrm{a}$ \\
\hline
\end{tabular}

Means followed by same letters in the line do not differ significantly from each other, Tukey test, $\mathrm{p}>0.05 ;{ }^{1} 100 \%$ equals to 215 and $314 \mathrm{~kg} / \mathrm{ha}$ of $\mathrm{N}$ and $\mathrm{K}$, respectively (Freitas, 2009); ${ }^{2} \mathrm{M}_{1}=$ fertigation managed according to the crop uptake rate; $\mathrm{M}_{2=}$ fertigation managed by monitoring the electrical conductivity of the soil solution; $\mathrm{M}_{3=}$ fertigation managed by monitoring $\mathrm{N}$ and $\mathrm{K}$ ionic concentration in the soil solution.

Table 4. Sweet pepper yield in protected cultivation with different fertigation management systems and nitrogen and potassium levels. Mossoró, UFERSA, 2010.

\begin{tabular}{lrcc}
\hline $\mathbf{N}$ and K & \multicolumn{3}{c}{ Sweet pepper yield (g/plant) } \\
\cline { 2 - 4 } level (\%) & \multicolumn{1}{c}{$\mathbf{M}_{1}{ }^{2 *}$} & $\mathbf{M}_{2}{ }^{2 *}$ & $\mathbf{M}_{3}{ }^{2 *}$ \\
\hline 0 & $589.9 \mathrm{a}$ & $589.9 \mathrm{a}$ & $589.9 \mathrm{a}$ \\
50 & $1487.0 \mathrm{a}$ & $1056.5 \mathrm{~b}$ & $1383.4 \mathrm{a}$ \\
100 & $1391.5 \mathrm{~b}$ & $1788.8 \mathrm{a}$ & $1452.6 \mathrm{ab}$ \\
150 & $1009.1 \mathrm{~b}$ & $1274.3 \mathrm{a}$ & $1399.6 \mathrm{a}$ \\
200 & $1082.1 \mathrm{~b}$ & $1381.7 \mathrm{a}$ & $1171.7 \mathrm{ab}$ \\
300 & $405.3 \mathrm{~b}$ & $1565.4 \mathrm{a}$ & $1425.7 \mathrm{a}$ \\
\hline
\end{tabular}

Means followed by same letters in the line do not differ significantly from each other, Tukey test, $\mathrm{p}>0.05$; ${ }^{*}$ Significant, $\mathrm{F}$ test, $\mathrm{p}>0.05 ;{ }^{1} 100 \%$ equals to 215 and $314 \mathrm{~kg} / \mathrm{ha}$ of $\mathrm{N}$ and $\mathrm{K}$, respectively (Freitas, 2009); ${ }^{2} \mathrm{M}_{1}=$ fertigation managed according to the crop uptake rate; $\mathrm{M}_{2}=$ fertigation managed by monitoring the electrical conductivity of the soil solution; $\mathrm{M}_{3=}$ fertigation managed by monitoring $\mathrm{N}$ and $\mathrm{K}$ ionic concentration in the soil solution.

dose (102 and $69 \mathrm{~g}$ /fruit per $\mathrm{g}$ of $\mathrm{N}$ and $\mathrm{K}$, respectively), in other words, managing fertigation through monitoring the ionic concentration of the soil solution was more efficient than through the crop uptake rate. In addition, it was observed that, although management $\mathrm{M}_{2}$ required the highest $\mathrm{N}$ and $\mathrm{K}$ doses to achieve maximum yield (140 and 89 $\mathrm{g}$ /fruit per $\mathrm{g}$ of $\mathrm{N}$ and $\mathrm{K}$, respectively), management $M_{2}$ was more efficient than $\mathrm{M}_{1}$ (95 and $72 \mathrm{~g}$ /fruit per $\mathrm{g}$ of $\mathrm{N}$ and $\mathrm{K}$, respectively). Sweet pepper yield responded more intensely to $\mathrm{N}$ than to $\mathrm{K}$, confirming reports from Aragão et al. (2011), who consider $\mathrm{N}$ as the most important nutrient for sweet peppers, since $\mathrm{N}$ directly influences plant and fruit growth. Oliveira et al. (2015), using the same fertigation management systems adopted here, found fertigation management based on ionic concentration in the soil solution provided adequate plant nutrition and high fertilizer savings.

Regardless of fertigation management, most fruits were 8 to $12 \mathrm{~cm}$ long (class 8) (Figure 1). The lowest frequency of longer fruits, class 12 (length between 12 and 15 $\mathrm{cm}$ ), was observed when fertigation was managed according to the crop uptake rate $\left(\mathrm{M}_{1}\right)(4.7 \%)$, while the lower frequencies of small fruits, class 6 (length between 6 and $8 \mathrm{~cm}$ ) were observed for management based on monitoring the electrical conductivity, $\mathrm{M}_{2}(8.9 \%)$, and the ion concentration of the soil solution, $\mathrm{M}_{3}(11.3 \%)$.

In fertigation management $\mathrm{M}_{1}$, increases in fertilization levels increased also the frequency of fruit class 6 and reduced frequencies of fruit classes 8 and 10 (Figure 1A). On the other hand, the highest frequency of fruit class 12 (11\%) was observed in the highest $\mathrm{N}$ and $\mathrm{K}$ levels. However, this was very likely due to the reduced number of fruits observed at this level, decreasing fruit competition for photoassimilates. Matos et al. (2012) state fruit demand for photoassimilates rises when there is a high number of fruits per plant, installing a strong fruit competition for assimilates.

For fertigation management $M_{2}$ the highest frequencies of fruit class $6,8,10$ and 12 occurred at 50, 0, 150 and $300 \%$ of the recommended $\mathrm{N}$ and $\mathrm{K}$ doses for sweet pepper in Mossoró (Freitas, 2009), with an increase in frequency of fruit class 12 in the highest $\mathrm{N}$ and $\mathrm{K}$ doses (Figure 1B). In $\mathrm{M}_{3}$, the increasing $\mathrm{N}$ and $\mathrm{K}$ doses raised frequencies of fruit classes 6,10 and 12, but reduced the number of fruits in class 8 . The highest frequencies of classes $6,8,10$ and 12 occurred at $200,0,150$ and $300 \%$ of $\mathrm{N}$ and $\mathrm{K}$, respectively (Figure 1C).

In summary, production of large fruits (class 12) was higher when fertigation was monitored by means either of the electrical conductivity $\left(\mathrm{M}_{2}\right)$ or the concentration of ions in soil solution $\left(\mathrm{M}_{3}\right)$. Reports on effect of $\mathrm{N}$ and $\mathrm{K}$ applied together, as in here, are scarce in literature. More abundant are studies evaluating the isolate effects of $\mathrm{N}$ and $\mathrm{K}$, as Araújo et al. (2009) and Melo et al. 


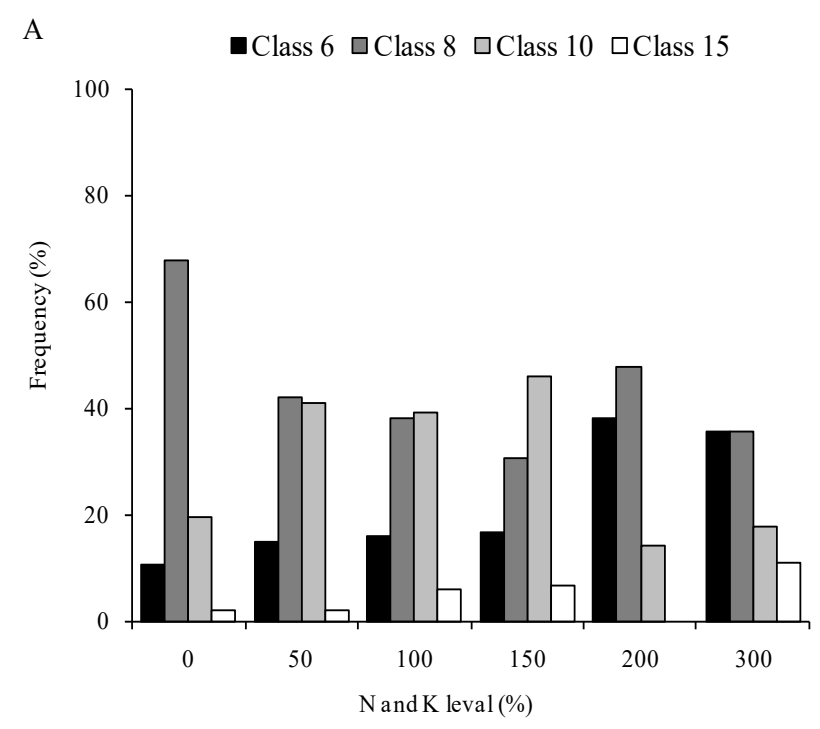

$\mathrm{B}$

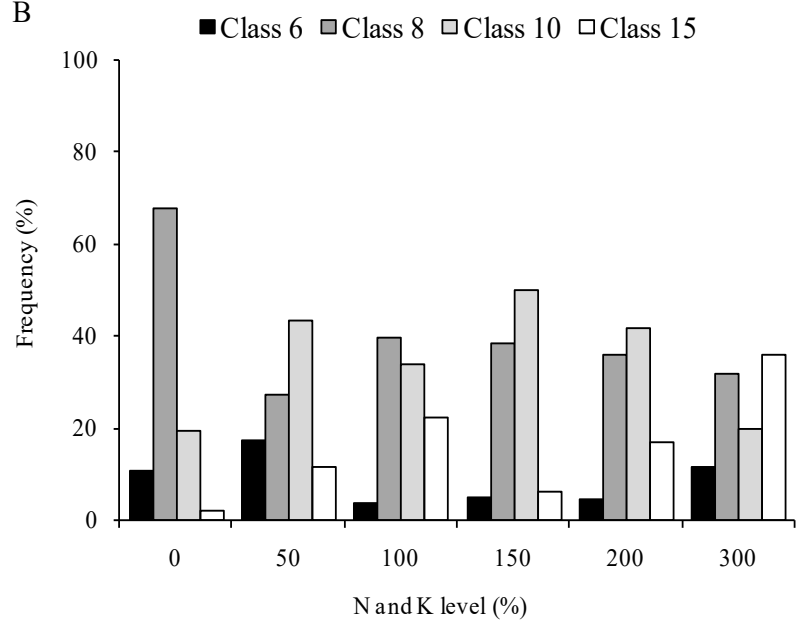

C

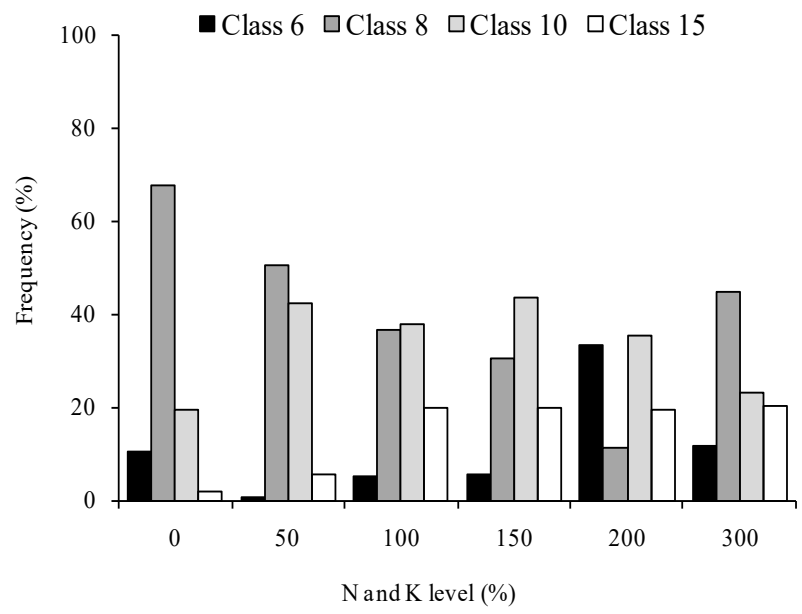

Figure 1. Fruit grading for sweet pepper grown in protected cultivation with different fertigation management systems and nitrogen and potassium levels. Figure $1 \mathrm{~A}, \mathrm{M}_{1}=$ fertigation managed according to the crop uptake rate; Figure $1 \mathrm{~B}, \mathrm{M}_{2=}$ fertigation managed by monitoring the electrical conductivity of the soil solution, and Figure $1 \mathrm{C}, \mathrm{M}_{3=}$ fertigation managed by monitoring $\mathrm{N}$ and $\mathrm{K}$ ionic concentration in the soil solution. Grading according to fruit length, as follows: class 6 (from 6 to $8 \mathrm{~cm}$ ), class 8 (from 8 to $10 \mathrm{~cm}$ ), class 10 (from 10 to $12 \mathrm{~cm}$ ), and class 12 (from 12 to $15 \mathrm{~cm}$ ). Mossoró, UFERSA, 2010.
(2009). These authors, working with $\mathrm{N}$ and $\mathrm{K}$ fertilization, respectively, found that adequate $\mathrm{N}$ and $\mathrm{K}$ doses increase production of large fruits.

The results obtained in the present work show that, in addition to the $\mathrm{N}$ and $\mathrm{K}$ applied dose, application management throughout the growing cycle is fundamental to improve yield and fruit quality in sweet pepper, as had been previously indicated by Oliveira et al. (2013). In the present case, managing fertigation by monitoring either the electrical conductivity $\left(\mathrm{M}_{2}\right)$ or the ionic concentration of the soil solution $\left(\mathrm{M}_{3}\right)$ resulted in better plant development and higher fruit yield and quality, with lower $\mathrm{N}$ and $\mathrm{K}$ demands. The control of $\mathrm{N}$ and $\mathrm{K}$ concentration in the soil solution, keeping them at 304 and $490 \mathrm{mg} / \mathrm{L}$ of $\mathrm{N}$ and $\mathrm{K}$, respectively, which corresponds to $200 \%$ of the recommendation for NFT hydroponic cultivation (152 and 245 $\mathrm{mg} / \mathrm{L}$ of $\mathrm{N}$ and $\mathrm{K}$, respectively), showed to be the most efficient for sweet pepper protected cultivation.

\section{REFERENCES}

ARAGÃO, VF; FERNANDES, PD; GOMES FILHO, RR; SANTOS NETO, AM; CARVALHO, CM; FEITOSA, HO. 2011. Efeito de diferentes lâminas de irrigação e níveis de nitrogênio na fase vegetativa do pimentão em ambiente protegido. Revista Brasileira de Agricultura Irrigada 5: 361-375.

ARAÚJO, JS; ANDRADE, AP; RAMALHO, CI; AZEVEDO, CAV. 2009. Cultivo do pimentão em condições protegidas sob diferentes doses de nitrogênio via fertirrigação. Revista Brasileira de Engenharia Agrícola e Ambiental 13: 559-565.

BLANCO, FF; FOLEGATTI, MV. 2002. Manejo da água e nutrientes para o pepino em ambiente protegido sob fertirrigação. Revista Brasileira de Engenharia Agrícola e Ambiental 6: 251255

CASTELlANE, PD; ARAÚJO, JAC. 1994. Cultivo sem solo: Hidroponia. Jaboticabal: FUNEP. 43 p.

CEAGESP. 2014. Norma de classificação do pimentão para o Programa Brasileiro para a melhoria dos padrões comerciais e embalagens de hortigranjeiros. Available in: http://www. alimentares.com/pimentas/_file/norma pimentoes.pdf $>$ Accessed in July 20, 2014.

DIAS, NS; DUARTE, SN; GHEYI, HR; MEDEIROS, JF; SOARES, TM. 2005. Manejo da fertirrigação e controle da salinidade do solo sob ambiente protegido, utilizando-se extratores de solução do solo. Revista Brasileira de Engenharia Agrícola e 
Ambiental 9: 496-504

EMBRAPA. 2009. Manual de análises químicas de solos, plantas e fertilizantes. Embrapa Informação Tecnológica. 2. ed. Brasília. 627p.

EPSTEIN, E; BLOOM, AJ. 2006. Nutrição mineral de plantas. Princípios e Perspectivas. 2.ed. Londrina: Editora Planta. 403p.

FAO (Roma, Italy). 1994. World reference base for soil resources: draft. Paris: UNESCO. 161p.

FERREIRA, DF. 2008. SISVAR: um programa para analises e ensino de estatística. Revista Cientifica Symposium 6: 36-41.

FONTES, PCR; DIAS, EN; GRAÇA, RN. 2005. Acúmulo de nutrientes e método para estimar doses de nitrogênio e de potássio na fertirrigação do pimentão. Horticultura Brasileira 23: 275-280.

FREITAS, KKC. 2009. Produção, qualidade e acúmulo de macronutrientes em pimentão cultivado sob arranjos espaciais $e$ espaçamentos na fileira. Mossoró: UFERSA. 110p. (Tese doutorado).

INSTITUTO DE ECONOMIA AGRÍCOLA. 2015. Banco de dados IEA, São Paulo. Available in: <http://www.iea.sp.gov.br/out/ banco/menu.php>. Accessed in May 20, 2016.

MARCUSSI, FFN; GODOY, LJG; VILLAS BÔAS, RL. 2004. Fertirrigação nitrogenada e potássica na cultura do pimentão baseada no acúmulo de N e K pela planta. Irriga 9: 41-51.

MAROUELLI, WA; SILVA, WLC. 2012. Irrigação na cultura do pimentão. $1^{\mathrm{a}} \mathrm{Ed}$. Brasília: Embrapa. 20p (Circular técnica, 101).

MATOS, ES; SHIRAHIGE, FH; MELO, PCT. 2012. Desempenho de híbridos de tomate de crescimento indeterminado em função de sistemas de condução de plantas. Horticultura Brasileira 30: 240-245.

MEDEIROS, PRF; DUARTE, SN; SILVA, EFF. 2012. Eficiência do uso de água e de fertilizantes no manejo de fertirrigação no cultivo do tomateiro sob condições de salinidade do solo. Revista Brasileira de Ciências Agrárias 7: 344-351.

MELO, AS; BRITO, MEB; DANTAS, JDM; SILVA JÚNIOR, CD; FERNANDES, PD; BONFIM, LV. 2009. Produção e qualidade do pimentão amarelo sob níveis de potássio em ambiente protegido. Revista Brasileira de Ciências Agrárias 4: 17-21.

OLIVEIRA, FA; DUARTE, SN; MEDEIROS, JF; DIAS, NS; OLIVEIRA, MKT; SILVA, RCP; LIMA KS. 2015. Nutrição mineral do pimentão submetido a diferentes manejos de fertirrigação. Horticultura Brasileira 33: 216-223.

OLIVEIRA, FA; DUARTE, SN; MEDEIROS, JF; DIAS, NS; SILVA, RCP; LIMA, CJGS. 2013.
Manejos da fertirrigação e doses de N e K no cultivo de pimentão em ambiente protegido. Revista Brasileira de Engenharia Agrícola e Ambiental 17: 1152-1159.

OLIVEIRA, MVAM; VILLAS BOAS, RL. 2008. Uniformidade de distribuição do potássio e do nitrogênio em sistema de irrigação por gotejamento. Engenharia Agrícola 28: 95-103.

PAPADOPOULOS, I. 1999. Fertirrigação: situação atual e perspectivas para o futuro. In: FOLEGATTI, MV (ed). Fertirrigação: citrus, flores, hortaliças. Guaíba: Agropecuária. p.11-84.

SILVA, EM; LIMA, CJGS; DUARTE, SN; BARBOSA, FS; MASCHIO, R. 2013. Níveis de salinidade e manejo da fertirrigação sobre características da berinjela cultivada em ambiente protegido. Revista Ciência Agronômica 44: 150-158.

SILVA JÚNIOR, MJ; DUARTE, SN; OLIVEIRA, FA; MEDEIROS, JF; DUTRA, I. 2010. Resposta do meloeiro à fertigação controlada através de íons da solução do solo: Desenvolvimento vegetativo. Revista Brasileira de Engenharia Agrícola e Ambiental 14: 715-722.

TAIZ, L; ZEIGER, E. 2009. Plant physiology. 3.ed. Porto Alegre: Artmed. 719p. 